\title{
Gênero televisivo como categoria cultural: um lugar no centro do mapa das mediações de Jesús Martín-Barbero'
}

TV genre as a cultural category: a place in the center of Jesús Martín-Barbero's map of mediations

Itania Maria Mota Gomes

Professora no Programa de Pós-Graduação em Comunicação e Cultura Contemporâneas da UFBA/BA/BR. itania@ufba.br

\begin{abstract}
RESUMO
Buscamos compreender os deslocamentos operados por Jésus Martín-Barbero no conceito de mediação e na configuração do mapa das mediações e, neste, o lugar dos gêneros televisivos. Argumentamos que, na sua obra, o conceito de mediação se consolida na direção da concepção de mediação na obra e que o mapa das mediações vai se definindo de modo a se configurar como um modelo de análise que possibilita olhar a totalidade do processo cultural. Argumentamos que, embora pareça hesitar entre uma concepção de gênero como categoria textual e uma concepção de gênero como estratégia de comunicabilidade, Martín-Barbero efetivamente constrói as bases para a definição de um conceito de gênero televisivo como categoria cultural e, nesse movimento, para uma abordagem analítica que tome em causa o processo de comunicação na sua vinculação com a cultura, a política e a sociedade.
\end{abstract}

Palavras-chave: gênero televisivo; mapa das mediações; Jesús Martín-Barbero

\section{ABSTRACT}

In this study we seek to understand the displacements that Jésus Martín-Barbero operates in the concept of mediation and the configuration of the map of mediations, and the place of television genres within that map. We argue that, in Barbero's work, the concept of mediation is consolidated towards the conception of mediation in the work, and that the map of mediations establishes itself in the form of an analytical model that allows us to view the entire cultural process. We further argue that, although he seems to waver between a concept of genre as a textual category and as a communicability strategy, Martín-Barbero effectively lays the foundations for establishing a concept of the television genre as a cultural category and, in the process, establishes an analytical approach that focuses on the process of communication and its relationship with culture, politics and society.

KeYwords: TV genre; map of mediations; Jesús Martín-Barbero 
Dara os estudos culturais, a análise dos processos comunicativos não tem por objetivo 1 compreender o funcionamento dos media em si mesmos e para si mesmos, mas compreender o funcionamento dos media na sua vinculação com cultura, sociedade, relações de poder. Parece-nos que uma das razões para que os estudos de gênero estejam relativamente ausentes dos estudos culturais é justamente o fato de que abordagens vindas das análises literárias e dos estudos do cinema, particularmente em perspectivas mais afinadas com o estruturalismo, mas não só, concebem o gênero como um elemento textual formal e, portanto, dificultam uma abordagem dos gêneros a partir de seus vínculos com cultura, política e sociedade. Por outro lado, quando se dedicam a analisar gêneros, abordagens vindas dos estudos culturais parecem tomar o gênero apenas como um pretexto para chegar à análise das relações de poder e da constituição de identidades ${ }^{2}$ e a ignorar a materialidade das obras, suas marcas expressivas e poéticas, em prol da consideração dos contextos de produção e recepção ${ }^{3}$.

Investigando a televisão, em especial o telejornalismo, no marco dos estudos culturais, vimos, ao longo dos últimos anos, buscando um conceito de gênero que permita quer o reconhecimento de regularidades e especificidades de formas culturais/televisivas, quer o reconhecimento de um modo distinto de configurar a relação comunicativa, dois aspectos fundamentais para configuração do que temos chamado de gênero televisivo ou midiático ${ }^{4}$. Buscamos um conceito de gênero que nos permita, sim, considerar aspectos textuais dos produtos televisivos, suas formulas (no sentido adotado por John Cawelti (1971) e Horace Newcomb $(1974)^{5}$, que possibilite organizar o mundo televisivo em categorias socialmente reconhecíveis, mas que não se restrinja à mera classificação/categorização dos produtos. Desejamos a formulação de um conceito de gênero e de um protocolo de análise que nos possibilite ir além das análises textuais, mas sem negá-las, sem recusá-las. Ao mesmo tempo, buscamos um conceito de gênero que nos permita a consideração de elementos contextuais do processo comunicativo, mas sem restringi-las a uma análise "pretextual", no sentido aqui daquelas abordagens mais gerais em que o programa televisivo é apenas um pretexto para análises macroeconômicas, sociológicas, para análises empíricas dos processos de produção ou de recepção que muitas vezes recusam-se a olhar o produto televisivo em seu aspecto propriamente comunicacional.

Assim, no atual momento do nosso percurso de investigação sobre a televisão, buscamos construir uma metodologia de análise de televisão que articule as relações entre comunicação, cultura, política e sociedade, através do conceito de gênero televisivo pensado como uma categoria 
cultural. Acreditamos que, tomado como categoria cultural, o gênero permite a construção, também, de um protocolo analítico para análise de televisão que permita uma visão global e complexa do processo comunicativo. Mas isso demanda um conceito de gênero em que este não apareça como uma entidade fixa, em que ele não seja apenas classificação ou tipologia da programação televisiva, mas que seja considerado como uma prática de produção de sentido que se realiza na "inter-relação entre uma variedade de práticas criativas, econômicas, sociais, tecnológicas, institucionais, industriais e interpretativas" (Edgerton; Rose, 2008, p. 7).

Jesus Martín-Barbero é um autor fundamental para a construção de uma nova abordagem dos gêneros televisivos, em razão de seu esforço de pensar modelos comunicativos que abarquem a totalidade do processo, por sua concepção de gênero como estratégia de comunicabilidade e por considerar o caráter contingente e transitório do gênero e as distintas temporalidades que ele convoca. Além do mais, ele investiga a televisão, toma o gênero televisivo como uma categoria cultural, adota uma abordagem fortemente historicizada e nos oferece pistas para pensar os vínculos entre comunicação, cultura, política e sociedade.

Em Dos meios às mediações, livro publicado originalmente em 1987, Jesús Martín-Barbero busca identificar as articulações entre as práticas comunicativas e os movimentos sociais, de modo a compreender "a materialidade social e a expressividade cultural da televisão" (2006a, p. 294). Em lugar de analisar as lógicas da produção ou da recepção, ele propõe partir do lugar onde se estabelece sua relação de enfrentamento, do lugar onde a relação entre os receptores e os meios acontece - o campo das mediações.

Mediação é um conceito que tem sido diversamente interpretado no Brasil e o próprio autor foi reconfigurando o conceito e apurando seu modelo de análise, adequando-o a novos problemas colocados pelos processos midiáticos e pela globalização. É esse processo de reconfiguração permanente de suas propostas analíticas que nos interessa aqui mais de perto.

Neste artigo, buscamos compreender os deslocamentos operados por Martín-Barbero no conceito de mediação e, mais especificamente, para o que nos interessa, na configuração do mapa das mediações e, neste, o lugar dos gêneros televisivos. No que se refere ao conceito de mediação, parece-nos que no livro Dos meios às mediações ele ainda fica a meio caminho da compreensão das mediações como um outro lugar ou um outro pólo a partir do qual pensar o processo comunicativo, pois, em vários momentos, colocar ênfase nas mediações é apenas colocar ênfase nas competências comunicativas dos receptores. Acreditamos que, posteriormente, o 
conceito de mediação se consolida na direção da concepção da mediação na obra e de um modelo que possibilite olhar o processo inteiro. Argumentamos que ao tempo em que o autor parece hesitar entre uma concepção de gênero como categoria textual e uma concepção de gênero como estratégia de comunicabilidade ou de interação, mais próxima de uma perspectiva pragmática, ele efetivamente constrói as bases para a definição de um conceito de gênero como categoria cultural e, nesse movimento, para uma abordagem analítica que tome em causa o processo de comunicação na sua vinculação com a cultura, a política e a sociedade. Assim, ele oferece mais um modelo de análise cultural do que especificamente comunicacional. E isso porque MartínBarbero entende que os processos e as práticas de comunicação coletiva põem em jogo profundas transformações na cultura. Essa é a razão, inclusive, para que ele pense que

$66[. .$.$] a expansão e interpenetração dos estudos culturais e da comunicação não são fortuitos nem$ ocasionais, respondem ao lugar estratégico que a comunicação ocupa tanto nos processos de reconversão cultural - que a nova etapa de modernização requer nestes países, - como na crise que a modernidade sofre nos países centrais. Não é possível compreender o cenário atual desses estudos sem pensar esta encruzilhada (Martín-Barbero, 1993, p. 61).

Assim, o que Martín-Barbero denomina como um mapa noturno para explorar o novo campo das mediações, em seu livro pioneiro, de 1987 (Martín-Barbero, 2006a), vai sendo testado a partir de outras questões teóricas, metodológicas e empíricas, o que permite ao autor pensar novas mediações e consolidar sua compreensão de que a recepção é um outro lugar a partir do qual o processo inteiro da comunicação deve ser analisado (Martín-Barbero, 19956); apresentar um novo mapa das mediações (Martín-Barbero, 2006b7); e, mais recentemente, em Ofício de Cartógrafo (MartínBarbero, $\left.2004^{8}\right)$, propor um novo mapa que pense as mediações comunicativas da cultura. Nesses dois últimos textos, Martín-Barbero claramente define suas preocupações em outros termos: não se trata apenas de deslocar o olhar dos meios às mediações, mas de olhar a cultura a partir da comunicação e da política. Vamos nos concentrar aqui nessas quatro formulações, de modo a buscar compreender os deslocamentos operados pelo autor.

Em Dos meios às mediações, ao invés de analisar as lógicas da produção ou da recepção, ele propõe partir do lugar onde se estabelece sua relação de enfrentamento, do lugar onde a relação entre os receptores e os meios acontece - o campo das mediações e propõe que devam ser 
consideradas três instâncias mediadoras para a análise da televisão: a cotidianidade familiar, a temporalidade social e a competência cultural.

A mediação que a cotidianidade familiar cumpre na configuração da televisão não se limita ao que é possível analisar desde o âmbito da recepção - o local ocupado pelo aparelho de TV no espaço doméstico, a legitimidade que as emissões televisivas possuem no seio da família, os horários e programações preferidas, o grau de atenção/dispersão com que se assiste TV, entre outros indicadores -, pois inscreve suas marcas no próprio discurso televisivo, através da simulação do contato, quando a TV interpela a família, convertendo-a em seu interlocutor, e da retórica do direto, dispositivos que organizam o espaço da televisão sobre o eixo da proximidade e da magia de ver (Martín-Barbero, 2006a, p. 295-297).

A simulação do contato atende à própria condição da recepção televisiva, que se dá no ambiente da dispersão característica à cotidianidade familiar. Mas atende, sobretudo, à necessidade de facilitar o aporte do mundo da ficção e do espetáculo ao espaço da cotidianidade e da rotina. A retórica do direto, por sua vez, diz respeito aos modos como a televisão busca operar sua proximidade em relação a seus espectadores, interpelando-os a partir dos dispositivos que dão forma à própria cotidianidade, como o imediatismo, a simplicidade, a clareza e a economia narrativa.

A temporalidade social, segunda mediação considerada por Martín-Barbero, refere-se às formas como a organização do tempo pela TV reproduz a mesma matriz cultural que organiza o tempo cotidiano, a da repetição e do fragmento, e que, segundo o autor, remete aos modos pelos quais a televisão inscreve o cotidiano no mercado (Martín-Barbero, 2006a, p. 298). Inserindo-se no tempo do ritual e da rotina, a televisão organiza sua programação como forma da rentabilidade:

66 O tempo com que organiza sua programação contém a forma da rentabilidade e do palimpsesto, um emaranhado de gêneros. Cada programa, ou melhor, cada texto televisivo remete seu sentido ao cruzamento de gêneros e tempos. Enquanto gênero, pertence a uma família de textos que se replicam e se reenviam uns aos outros nos diferentes horários do dia e da semana. Enquanto tempo 'ocupado', cada texto remete à seqüência horária daquilo que o antecede e daquilo que o segue, ou àquilo que aparece no palimpsesto nos outros dias, no mesmo horário (Martín-Barbero, 2006a, p. 298) .

Se o fragmento e a repetição reproduzem o cotidiano, a serialidade da programação de TV remete ao tempo produtivo: "o tempo da série fala o idioma do sistema produtivo - o da 
estandardização [...] A série e os gêneros fazem agora a mediação entre o tempo do capital e o tempo da cotidianidade" (Martín-Barbero, 2006a, p. 298).

Em América Latina e os anos recentes, Martín-Barbero amplia sua concepção das mediações da temporalidade de modo que elas não se refiram especificamente ao "tempo da TV", mas encontrem ressonância na "multiplicidade de temporalidades, [na] multiplicidade de histórias, com seus próprios ritmos e com suas próprias lógicas" (Martín-Barbero, 1995, p. 43). Apoiado em Raymond Williams (1979), Martín-Barbero pretende chamar atenção para a heterogeneidade de temporalidades vividas por cada sociedade ou, em outros termos, para o fato de que "em toda sociedade convivem formações culturais arcaicas, residuais e emergentes" (Martín-Barbero, 1995, p. 44).

Ele acrescenta também, nesse texto de 1995, três outras mediações - a mediação das novas fragmentações sociais e culturais, a mediação da exclusão cultural e a mediação das demandas sociais -, dá formulação complementar à mediação da temporalidade e formula algumas das suas preocupações com a tecnicidade e a socialidade (mediações que serão efetivamente formuladas mais adiante, apenas no prefácio à edição espanhola e em Ofício de Cartógrafo). Na mediação das novas fragmentações sociais e culturais, Martín-Barbero considera, sobretudo, a segmentação dos públicos com os quais os meios trabalham, segmentação cada vez mais matizada e que se põe como estratégia mercadológica em razão das novas tecnologias da comunicação, como as redes de satélites, as TVs a cabo e por assinatura. Mas o autor está interessado nas fragmentações sociais e culturais engendradas pela tecnologia, como, por exemplo, aquela que dá nova roupagem ao velho tema da diferença de gerações: a separação entre jovens e velhos em razão dos "novos modos de relação da juventude com a tecnologia eletrônica" (Martín-Barbero, 1995, p. 46). Essas novas mediações são claramente resultado do esforço do autor para compreender o modo como os aparatos eletrônicos reorganizam a experiência social dos jovens. A mediação da exclusão cultural implica a consideração de três modos de deslegitimação e de desqualificação do gosto popular: uma deslegitimação do gosto popular como mau-gosto ou não-gosto; uma deslegitimação da cultura dos gêneros narrativos; e "uma deslegitimação dos modos populares de recepção, dos modos populares de desfrutar as coisas" (Martin-Barbero, 1995, p. 52). Finalmente, haveria, segundo Martín-Barbero, um acúmulo de demandas sociais de comunicação que se expressam nos modos de ver, de escutar e de ler. São demandas que de certo modo traduzem a multiplicidade de atores da sociedade civil e que não têm sido consideradas pelas políticas de comunicação na América Latina. 
Mas o que era apenas um mapa noturno, um mapa que nos permitiria "avançar tateando", que serviria "para questionar as mesmas coisas - dominação, produção e trabalho - mas a partir do outro lado: as brechas, o consumo, o prazer", que permitiria "o reconhecimento da situação a partir das mediações e dos sujeitos" (Martín-Barbero, 2006a, p. 290), transforma-se no novo mapa das mediações que o autor desenha em Pistas para entre-ver meios e mediações e consolida em Ofício de Cartógrafo.

O esquema de Martín-Barbero move-se sobre dois eixos, um diacrônico, entre as matrizes culturais e os formatos industriais, e um sincrônico, entre as lógicas de produção e competências de recepção ou consumo. Claramente, a configuração desses dois eixos permite a Martín-Barbero incor-

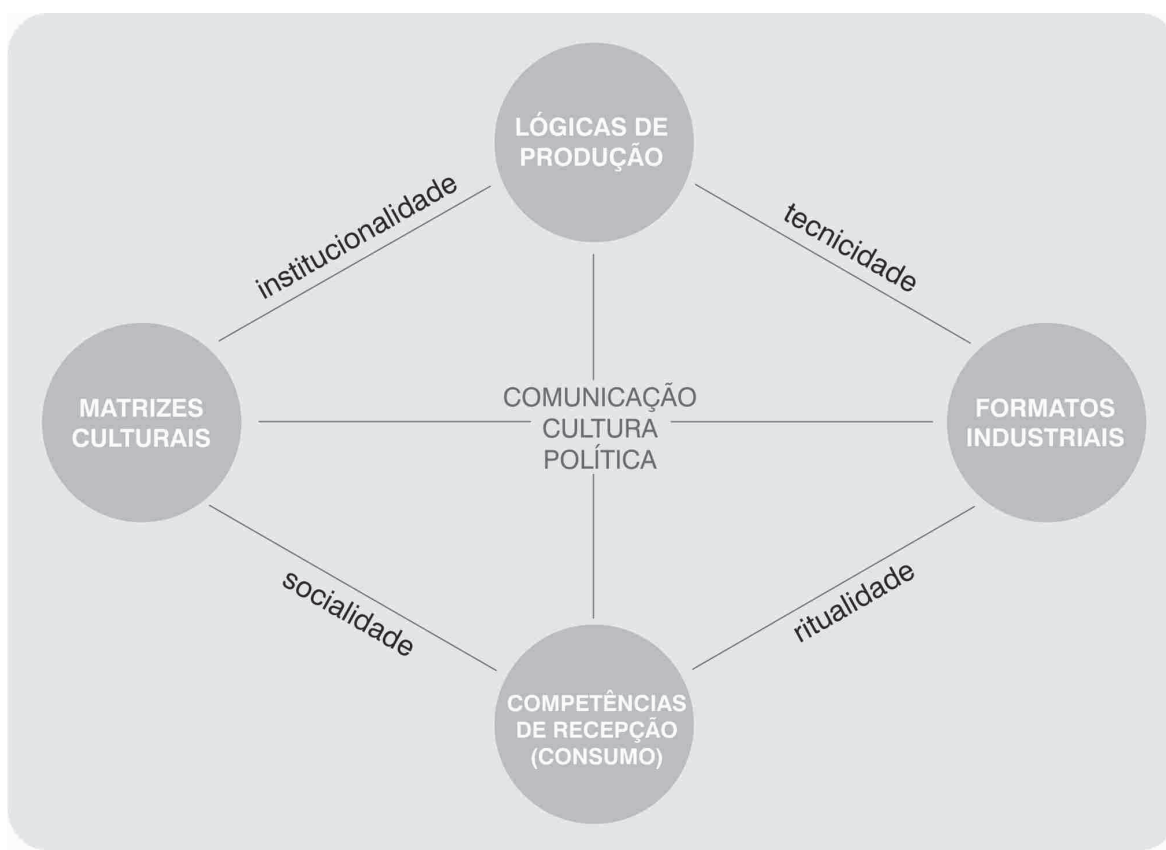

Fig. 1 - Martín-Barbero, 2006b, p. 16, segundo desenho de Ronsini, 2010. porar a uma proposta metodológica mais consistente a preocupação que ele tem, desde o início, com a heterogeneidade de temporalidades (que aparece em Dos meios às mediações como mediação da temporalidade social e que permanece como mediação em América Latina e os anos recentes). Para o autor, é fundamental compreender a relação histórica que marca a passagem das matrizes culturais aos formatos industriais, o que para ele significa remeter "à história das mudanças na articulação entre movimentos sociais e discursos públicos e destes com os modos de produção do público que agenciam as formas hegemônicas de comunicação coletiva" (Martín-Barbero, 2006b, 16).

Para compreendermos a relação entre matrizes culturais e formatos industriais é fundamental recorrermos às noções de dominante, residual e 
emergente que Raymond Williams utiliza em Marxismo e Literatura para descrever elementos de diferentes temporalidades e origens que configuram o processo cultural. Segundo Williams (1979, p. 124), é claro que a análise cultural deve considerar as características dominantes de um determinado processo ou sistema cultural, mas o analista precisa estar atento também a um certo senso de movimento, de processo histórico, e às articulações e inter-relações complexas entre esses elementos dominantes e os residuais (aqueles elementos que foram efetivamente formados no passado, mas ainda estão ativos no processo cultural, não só como elemento do passado, mas como um elemento efetivo do presente) e emergentes (novos significados e valores, novas práticas, novas relações e tipos de relação que são efetivamente criados e que aparecem como substancialmente alternativos ou opostos na cultura dominante). Segundo Martín-Barbero, o modo como Raymond Williams propõe pensar a dinâmica cultural tem duas frentes. Na frente teórica, Williams introduz o conceito gramsciano de hegemonia para enfrentar a concepção redutora de ideologia como reprodução ${ }^{10}$. Na metodológica, Williams proporia "uma tipologia das formações culturais que apresenta três 'estratos': arcaico, residual e emergente" (MartínBarbero, 2006a, p. 117-118).

Efetivamente, as noções centrais para Williams - e que dão título ao capítulo 8 da Parte II Teoria Cultural, de Marxismo e Literatura, são as de residual, dominante e emergente. Williams se refere aos elementos arcaicos apenas para marcar a distinção com o que ele compreende como elementos residuais. Arcaico é

$66[. .$.$] aquilo que é totalmente reconhecido como um elemento do passado, a ser observado, examinado,$ ou mesmo, ocasionalmente, a ser 'revivido' de maneira consciente, de uma forma deliberadamente especializante. $\mathrm{O}$ que entendo pelo 'residual' é muito diferente. $\mathrm{O}$ residual, por definição, foi efetivamente formado no passado, mas ainda está ativo no processo cultural, não só como elemento do passado, mas como um elemento efetivo do presente (Williams, 1979, p. 125).

De todo modo, o fundamental na análise cultural de Williams, e que é captado por MartínBarbero na construção do seu mapa das mediações, é a crucial importância da consideração das diversas temporalidades sociais em qualquer análise da cultura. Para Martín-Barbero, a consideração da heterogeneidade de temporalidades significa "uma nova maneira de introduzir a dimensão histórica nos processos de comunicação" (Martín-Barbero, 1995, p. 44), o que ele faz 
ao pensar na mediação da relação histórica das matrizes culturais com os formatos industriais, mas também com as lógicas de produção e com as competências de recepção.

As matrizes culturais se articulam com as lógicas de produção pelos movimentos de institucionalidade e com as competências de recepção pelos movimentos de sociabilidade - ou socialidade. A institucionalidade aparece então como "uma mediação densa de interesses e poderes contrapostos" (Martín-Barbero, 2006b, p. 17), que afetam a regulação dos discursos e dos meios, do Estado e dos cidadãos. É onde atuam o Estado, os poderes constituídos, as empresas, as organizações sociais, as instituições que representam a realidade das minorias e da maioria. Martín-Barbero chama atenção para o modo como novos movimentos sociais estão buscando a construção de outras institucionalidades. Daí porque é fundamental, para análise da televisão, tomar em consideração a legislação, as agências reguladoras, o papel do Estado e das organizações da sociedade civil e as disputas discursivas na definição das políticas de comunicação e cultura.

A socialidade, mediação que articula matrizes culturais e competências de recepção, deixa ver os modos e usos coletivos de comunicação, as relações cotidianas que as pessoas estabelecem com os meios, com os gêneros e formatos midiáticos. Não por acaso, Martín-Barbero recorre ao conceito de habitus de Pierre Bourdieu (2001), como uma disposição pessoal que é sempre resultado do processo de socialização, ou uma subjetividade socializada, que organiza práticas e a percepção das práticas: "as matrizes culturais ativam e moldam os habitus que conformam as diversas Competências de Recepção" (Martín-Barbero, 2006b, p. 17). Em Ofício de Cartógrafo o autor é explícito: "a socialidade dá nome à trama de relações cotidianas que tecem os homens ao se juntar, e nas quais se ancoram os processos primários de interpelação e constituição de sujeitos e identidades" (Martín-Barbero, 2004, p. 230), que é o que constitui o sentido da comunicação como uma questão de fins e não apenas de meios, de aparato. A socialidade é uma outra dimensão da sociedade, aquela que permite ver a vida cotidiana como espaço em que a sociedade se produz - e não apenas se reproduz; aquela que nos obriga a pensar a partir do conceito de hegemonia, que torna visível o fato de que a vida cotidiana tem um papel muito mais importante na produção do tecido social (Martín-Barbero, 1995, p. 59). A mediação da socialidade implica analisar os processos comunicativos não só do ponto de vista das determinações e estruturas, mas do ponto de vista das práticas, das apropriações cotidianas que podem fazer surgir processos não hegemônicos de significação - ainda que o mapa das mediações considere também as determinações e estruturas, em especial quando considera a relação entre lógicas da produção e formatos industriais. 
No mapa das mediações, as lógicas de produção se relacionam com os formatos industriais através da mediação da tecnicidade, que acontece num cenário de globalização e de convergência midiática. A compreensão das lógicas de produção demanda a investigação sobre a estrutura empresarial, em suas dimensões econômicas, suas ideologias profissionais e as rotinas produtivas; a competência comunicativa, sua "capacidade de interpelar/construir públicos, audiências, consumidores" (Martín-Barbero, 2006b, p. 18), e a competitividade tecnológica, que não nos fala exclusiva e redutoramente dos meios apenas como aparatos técnicos, mas de suas destrezas discursivas e de sua capacidade de funcionar como operadores perceptivos. Na discussão que faz sobre a mediação das novas fragmentações sociais e culturais em América Latina e os anos recentes, o autor já explicitava suas preocupações com a tecnicidade: a tecnologia se apresenta como "um novo organizador perceptivo, um reorganizador da experiência social, no sentido forte da experiência, no sentido da sensibilidade, do sensorium a que se referia Walter Benjamim [...]" (Martín-Barbero, 1995, p. 46). Na sua obra mais recente, Martín-Barbero dirá que “tecnicidade é competência na linguagem" (2004, p. 235).

A ritualidade é a mediação que conecta os formatos industriais com as competências da recepção e remete-nos ao nexo simbólico que sustenta toda comunicação: "ao mesmo tempo repetição e inovação, âncora na memória e horizonte aberto" (Martín-Barbero, 2004, p. 231). A ritualidade nos permite ver que a relação entre formatos industriais e competências da recepção diz respeito à sua ancoragem na memória, aos seus ritmos e formas, seus cenários de interação e repetição. Na relação com as competências de recepção, a mediação da ritualidade convoca olhar os diferentes usos sociais dos meios e as múltiplas trajetórias de leituras, que são sempre ligadas às condições sociais do gosto, aos hábitos familiares de consumo cultural e midiático, aos saberes constituídos na memória étnica, de classe ou de gênero.

Em sua relação com os formatos industriais (discursos, gêneros, programas, grades ou palimpsestos), as ritualidades constituem gramáticas de ação - do olhar, do escutar, do ler que regulam a interação entre os espaços e tempos da vida cotidiana e os espaços e tempos que conformam os meios (Martín-Barbero, 2006b, p. 19). Na constituição dos formatos industriais, a ritualidade deixa ver uma certa capacidade dos meios para impor regras ao jogo da significação. Martín-Barbero ressalta, porém, que a imposição de regras se dá na ordem da construção dos processos de significação, mas que é fundamental considerar a relação entre formatos industriais e competências da recepção também do ponto de vista pragmático, ou seja, da consideração dos 
processos de produção de sentido que se dão necessariamente como uma relação entre texto e contexto midiático/televisivo.

Em Ofício de Cartógrafo, o autor propõe pensar também as mediações das estruturas sociais, das lógicas de produção, das dinâmicas culturais e das gramáticas discursivas como modo de articular a análise e a crítica à produção. Investigar as estruturas sociais significa evitar que a inteligibilidade do social fique dissolvida na fragmentação das práticas cotidianas das novas sensibilidades, da deriva e da diferença. Quanto às lógicas de produção, o autor enfatiza a análise de "ao menos duas, a da acumulação/rentabilidade do capital e a do processo industrial, com fortes laços de cumplicidade entre ambas, porém diferentes" (Martín-Barbero, 2004, p. 237). Com a consideração das dinâmicas culturais o autor quer se referir aos processos de incorporação das maiorias à modernidade da cultura audiovisual, dinâmicas de fragmentação dos públicos, da multiplicação dos canais e da segmentação especializada do consumo, o que já era uma preocupação manifestada também no América Latina e os anos recentes. Com as gramáticas discursivas o autor propõe a investigação sobre "as estratégias comunicativas nas quais se faz a osmose das matrizes estéticas e dos formatos comerciais" ou, mais especificamente, "gramáticas configuradas por práticas de enunciação de atores situados tanto na produção quanto na recepção, e por formatos de sedimentação de saberes narrativos, hábitos e técnicas expressivas" (Martín-Barbero, 2004, p. 238). Essas gramáticas discursivas

$66[\ldots]$ dão lugar a uma topografia de discursos movediça e em constante evolução, exigida não só pela renovação do capital e pelas transformações tecnológicas, mas também pela movimentação permanente das intertextualidades que alimentam os diferentes gêneros nas diferentes mídias. Gramáticas que são lugar de complexos 'tecidos' de resíduos e inovações, de anacronias e modernidades, de assimetrias comunicativas que envolvem, da parte dos produtores, sofisticadas 'estratégias de antecipação' e, da parte dos espectadores, a ativação de competências de leitura e operadores de apropriação (Martín-Barbero, 2004, p. 238).

O mapa das mediações consolida um programa de investigação em comunicação e claramente configura uma proposta bem sucedida de Jésus Martín-Barbero de analisar os processos comunicativos em sua totalidade, ou seja, não só do ponto de vista das determinações e estruturas, mas do ponto de vista das práticas, das apropriações cotidianas, sem, no entanto, fazer o movimento inverso, que seria o de desligar o estudo da recepção dos processos de produção, 
da consideração da concentração econômica dos meios, da reorganização da hegemonia política e cultural em nossas sociedades: "eu não gostaria que o estudo da recepção viesse a nos afastar dos problemas nucleares que ligam a recepção com as estruturas e condições de produção" (Martín-Barbero, 1995, p. 55).

Chegamos ao ponto em que os gêneros aparecem como um elemento-chave para compreensão da relação televisão e cultura:

$66[$ [...] a dinâmica cultural da televisão atua pelos seus gêneros. A partir deles, ela ativa a competência cultural e a seu modo dá conta das diferenças sociais que a atravessam. Os gêneros, que articulam narrativamente as serialidades, constituem uma mediação fundamental entre as lógicas do sistema produtivo e do sistema de consumo, entre a do formato e a dos modos de ler, dos usos (MartínBarbero, 2006a, p. 300-301).

Em Dos meios às mediações, os gêneros estão fortemente vinculados a uma das mediações mais importantes na proposta formulada pelo autor, a da competência cultural, pois eles permitiriam a compreensão da especificidade do cultural no massivo. Os gêneros são compreendidos por Martín-Barbero no sentido que lhes deu Paolo Fabbri (1973): como a unidade mínima do conteúdo da comunicação de massa, capaz de articular o público e os produtores. É certo, entretanto, que Paolo Fabbri realiza o esforço de definição de uma tipologia dos discursos, postulando um duplo funcionamento textual do discurso na sociedade. Apoiando-se em Todorov, Fabbri afirma:

$66[\ldots]$ enquanto, na alta cultura, a obra está, ao menos hoje, em contradição dialética com seu gênero, na cultura de massa a regra 'estética' é aquela (pré-romântica) da maior adequação ao gênero. Se pode dizer que o próprio gênero é a unidade mínima do conteúdo da comunicação de massa [...] e que a demanda de mercado por parte do público (e do meio) aos intelectuais produtores se faz no nível do gênero [...] é através da percepção do gênero que se alcança o sentido latente dos textos massmidiáticos (Fabbri, 1973, s/no $)^{11}$.

Jesús Martín-Barbero parece hesitar entre uma concepção de gênero como categoria textual e uma concepção de gênero como categoria cultural - o que pode ser explicado pelo contexto intelectual e acadêmico em que produziu suas reflexões e pelo próprio estágio de amadurecimento do conceito na sua obra. Entretanto, quando precisa marcar posição sobre o assunto, ele é firme: 
66 Claro que a noção de gênero que estamos trabalhando tem pouco a ver com a velha noção literária do gênero como 'propriedade' de um texto, e muito pouco também com a sua redução taxonômica, empreendida pelo estruturalismo. No sentido em que estamos trabalhando, um gênero não é algo que ocorra no texto, mas sim pelo texto, pois é menos questão de estrutura e combinatórias do que de competência [...] A consideração dos gêneros como fato puramente 'literário' - não cultural - e, por outro lado, sua redução a receita de fabricação ou etiqueta de classificação nos têm impedido de compreender sua verdadeira função e sua pertinência metodológica: chave para análise dos textos massivos e, em especial, dos televisivos (Martín-Barbero, 2006a, p. 303-304).

Ou no livro mais recente:

66 Não me refiro à categoria literária de gênero, mas a um conceito que deve ser situado entre a antropologia e a sociologia da cultura, isto é, ao funcionamento social dos relatos, funcionamento diferencial e diferenciador, cultural e socialmente discriminatório. E que atravessa tanto as condições de produção como as de consumo (Martín-Barbero, 2004, p. 161).

Ainda que não explore todas as consequências do que diz, o autor nos oferece boas pistas para consolidar o estatuto do gênero como uma categoria cultural: em primeiro lugar, porque entende que o gênero é uma estratégia de comunicabilidade ou de interação, e é como marca dessa comunicabilidade que ele se faz presente e analisável em um texto, numa perspectiva que se aproxima mais de uma pragmática da comunicação do que de uma semiótica textual de viés imanentista; segundo, porque postula o gênero como um elemento central para compreensão da relação entre televisão e cultura.

Gênero não é uma propriedade dos textos, mas algo que perpassa os textos; não é uma estratégia da produção dos textos, mas uma estratégia que vincula a produção e o consumo dos textos midiáticos, que vincula estratégias de escritura e de leitura. Por isso Martín-Barbero entende que o gênero é uma estratégia de comunicação e, ainda mais, uma estratégia ligada aos vários universos culturais. "O gênero é um estratagema da comunicação, completamente enraizado nas diferentes culturas, por isso, geralmente, não podemos entender o sentido dos gêneros senão em termos de sua relação com as transformações culturais na história" (Martín-Barbero, 1995, p. 65).

O entendimento dos gêneros como estratégias de interação, como modos nos quais se fazem presentes, reconhecíveis, as competências comunicativas dos emissores e dos destinatários é um 
dos grandes saltos da proposta de Martín-Barbero rumo a uma análise do processo comunicativo como um todo. É o funcionamento dessas estratégias de interação que vai impor uma diferente concepção da comunicação, na medida em que obriga a pensar a competência textual fora do âmbito de uma exclusividade da emissão, senão também da recepção.

Sugerindo que o melodrama é o gênero televisivo mais expressivo na América Latina porque é o mais aberto às formas de viver e sentir de sua população, Martín-Barbero procurará identificar, no melodrama, os mecanismos através dos quais, operando desde a memória e o imaginário coletivo, ele irá dar conta do reconhecimento da cultura popular na cultura de massa. É o drama do reconhecimento o que está em jogo no melodrama e reconhecimento, na acepção adotada, significa interpelação:

$66[$ [...] re-conhecer significa interpelar, uma questão acerca dos sujeitos, de seu modo específico de constituir-se. E não somente os individuais, também os coletivos, os sociais, incluídos os sujeitos políticos. Todos se fazem e refazem na trama simbólica das interpelações, dos reconhecimentos (Martín-Barbero, 2006a, p. 306).

Os gêneros acionam mecanismos de percepção e de reconhecimento do popular; eles não são apenas qualidade dos textos, ou da narrativa, mas um mecanismo que funciona como dispositivo de leitura, de produção de sentido, de "reencontro com o mundo" (Martín-Barbero, 2006a, p. 204) e são, por este motivo, o ponto de ancoragem da indústria midiática no aparato perceptivo das massas. É justamente uma abordagem pragmática que poderia dar conta do modo como os gêneros operam seu reconhecimento numa comunidade cultural.

Gênero permite a Martín-Barbero, portanto, reconhecer, a partir do melodrama, o modo como o massivo opera de dentro do popular ou o modo como a cultura midiática ao mesmo tempo em que se impõe ao povo, através das corporações midiáticas com suas lógicas de produção, também deriva de experiências, gostos e costumes populares que configuram as lógicas de consumo e usos. De fato, em Ofício de cartógrafo ele dirá que "o gênero constitui uma categoria básica para investigar o popular e o que de popular fica ainda no massivo" (Martín-Barbero, 2004, p. 161).

Se explorarmos as consequências das proposições de Martín-Barbero sobre o gênero e ampliarmos o olhar para além do texto, veremos que o gênero ocupa lugar no centro do mapa das mediações, naquele ponto de entrecruzamentos onde o autor acredita poder investigar as relações 
entre comunicação, cultura e política. Argumentamos aqui que, se o gênero é uma estratégia de comunicabilidade que articula lógicas de produção com competências de recepção e matrizes culturais com formatos industriais, ele não pode estar em outro lugar.

O gênero, como categoria cultural, se deixa ver na articulação dos dois eixos do mapa das mediações, o diacrônico, que diz dos modos como as matrizes culturais se relacionam com a constituição de formatos industriais (nos termos de Martín-Barbero, como matrizes populares se fazem presentes na configuração de produtos massivos), e o sincrônico, entre as lógicas de produção e competências de recepção ou consumo (nos termos de Martín-Barbero, o modo como as lógicas do sistema produtivo, ou seja, sua estrutura e suas dinâmicas se articulam com as competências culturais dos diversos grupos sociais). Pensado assim, o gênero nos permite uma chave de análise da televisão que a vincule a uma das principais teses da teoria da cultura de Martín-Barbero: não podemos pensar o popular à margem do processo histórico de constituição do massivo. Vejamos como o autor relaciona o gênero com esses dois eixos.

No eixo diacrônico:

66 O gênero é hoje um lugar-chave da relação entre matrizes culturais e formatos industriais e comerciais. Temos vivido separando completamente estas duas coisas. Uma coisa era o estudo dos textos literários ou das matrizes culturais, e outra, o estudo dos formatos. O gênero é lugar de osmose, de fusão e de continuidades históricas, mas também de grandes rupturas, de grandes descontinuidades entre essas matrizes culturais, narrativas, gestuais, estenográficas, dramáticas, poéticas em geral, e os formatos comerciais, os formatos de produção industrial (Martín-Barbero, 1995, p. 66).

\section{No eixo sincrônico:}

66 Entre a lógica do sistema produtivo e as lógicas dos usos, medeiam os gêneros. São suas regras que configuram basicamente os formatos, enestes se ancora o reconhecimento cultural dos grupos (Martín-Barbero, 2006a, p. 303).

Ou ainda:

66 Os gêneros não podem ser estudados sem uma redefinição da própria concepção que se teve da comunicação. Pois seu funcionamento nos coloca diante do fato de que a competência textual, 
narrativa, não se acha apenas presente, não é unicamente condição da emissão, mas também da recepção. Qualquer telespectador sabe quando um texto/relato foi interrompido, conhece as formas possíveis de interpretá-lo, é capaz de resumi-lo, dar-lhe um título, comparar e classificar narrativas. Falantes do 'idioma' dos gêneros, os telespectadores, como nativos de uma cultura textualizada, 'desconhecem' sua gramática, mas são capazes de falá-lo (Martín-Barbero, 2006a, p. 304).

Claramente, a configuração desses dois eixos permite a Martín-Barbero incorporar à sua proposta de análise da televisão a preocupação que ele tem, desde o início, com a heterogeneidade de temporalidades vividas por cada sociedade. Na concepção do autor, a relação entre matrizes culturais e formatos industriais implica a articulação entre gramáticas gerativas, que se articulam às mudanças do capital, mas também às mudanças tecnológicas,

$66[\ldots]$ do movimento permanente das intertextualidades e intermedialidades que alimentam os diferentes gêneros e os diferentes meios. E que hoje são lugar de complexos entremeados de resíduos (R. Williams) e inovações, de anacronismos e modernidades, de assimetrias comunicativas que envolvem, da parte dos produtores, sofisticadas 'estratégias de antecipação' (M. Wolf) e, da parte dos espectadores, a ativação de novas e velhas competências de leitura. Essa história encaminha-se justamente para a perspectiva dos chamados 'estudos culturais'(Martín-Barbero, 2006b, p. 17) ${ }^{12}$.

A articulação entre as lógicas de produção e as competências da recepção se faz pelos distintos modos com a TV incorpora o tempo da vida cotidiana. E como exemplo da relação entre matrizes culturais e formatos industriais, o autor convoca a história de como o melodrama vai do teatro ao folhetim, à novela, ao cinema, ao radioteatro e à telenovela, articulando a memória popular ao imaginário burguês. Para Martín-Barbero,

$66[\ldots]$ essa história nos permite deslocar o maniqueísmo estrutural que nos incapacitou durante muito tempo para pensar a trama das cumplicidades entre discursos hegemônicos e subalternos, assim como a constituição - ao longo dos processos históricos - de gramáticas discursivas originadas de formatos de sedimentação de saberes narrativos, hábitos e técnicas expressivas (Martín-Barbero, 2006b, p. 17).

Pensar o gênero televisivo como uma categoria cultural e colocá-lo no centro do mapa das mediações implica, para nós, um olhar que efetivamente procure compreender os elementos 
de distintas temporalidades e origens que configuram o processo cultural. Se concordarmos que os gêneros são um elemento fundamental para compreensão da relação entre televisão e cultura, devemos analisar os gêneros em sua relação com as transformações culturais na história. Eles devem nos permitir analisar a dinâmica cultural da televisão, os modos como ela articula efetivamente elementos de distintas temporalidades: um presente-passado/residual, um presente-presente/dominante, um presente-futuro/emergente (Williams, 1979). Tomar o gênero numa perspectiva histórica não é apenas olhar para um conjunto de textos pertencentes a um determinado gênero - na medida em que gêneros não são redutíveis aos textos - mas olhar para a circulação cultural dos gêneros televisivos para compreender como os gêneros surgem, mudam, desaparecem.

Acreditamos que colocar o gênero no centro do mapa das mediações é uma boa pista para a construção de um modelo de análise que articule as relações entre comunicação, cultura, política e sociedade e que permita uma visão global e complexa do processo comunicativo. Argumentamos que nossa leitura é conceitualmente coerente com a perspectiva do autor e mostra-se bastante produtiva, do ponto de vista metodológico, para uma análise de gênero que tem por ambição abarcar o processo inteiro da comunicação. Compreender o gênero como uma categoria cultural e colocá-lo no centro do mapa das mediações tem a vantagem de permitir compreender os gêneros em sua relação com as transformações culturais, numa perspectiva histórica, e a enfrentar o desafio metodológico implicado na ambição de adotar uma visão global e complexa do processo comunicativo. Nesse caso, acreditamos ser fundamental a concepção de mediação, pensada por Martín-Barbero, mas como mediação na obra: como uma determinada obra, um determinado programa televisivo, no processo analítico, convoca nosso olhar para o processo cultural do qual participa.

\section{NOTAS}

1 Este artigo é resultado de pesquisa realizada com apoio do Conselho Nacional de Desenvolvimento Científico e Tecnológico/CNPq através de bolsa de Produtividade em Pesquisa.

2 Um bom exemplo pode ser encontrado em Butsch, 2008.

3 Só o desconhecimento da materialidade textual dos programas televisivos pode levar alguns autores a considerar de mesmo gênero programas textualmente tão díspares quanto desenhos animados, programas de auditório e 
programas educativos (poderíamos pensar nos desenhos da Turma da Mônica, no Programa da Xuxa e no Rá-TimBum como exemplos) para falar de um gênero programa infantil (ver Pecora, 2008). Ou a pensar em talk genre, que reuniria programas tão díspares quanto talk shows, telejornais e reality shows, como um gênero, apenas baseado no critério de que todos se organizam a partir da conversação (ver Jones, 2008). Nesse caso, é de se pensar qual a validade teórica e metodológica de se definir um gênero por um elemento comum a todos os programas televisivos - a conversação. Esses são dois casos em que o recurso ao conceito de gênero não contribui para uma melhor compreensão da televisão.

4 Ver, a esse respeito, Gomes, 2007.

5 Numa análise mais recente das contribuições e limites do seu livro pioneiro, Newcomb lembra que o termo analítico que Cawelti aplicou no seu estudo do Western e que ele mesmo utilizou no estudo da televisão não foi o de gênero, mas o de fórmula. Gênero ainda era um termo reservado para a arte. "Em retrospectiva, ele parece de algum modo condescendente. É mecânico ou, melhor, químico, uma mistura de elementos que, se realizada corretamente, feita do mesmo jeito por qualquer um, daria no mesmo resultado [...] É uma receita [...]" (2008, p. 22). Todas as traduções de textos originais em língua estrangeira foram feitas pela autora.

6 No artigo América Latina e os anos recentes: o estudo da recepção em comunicação social, apresentado num seminário em 1991 e publicado em 1995 no livro Sujeito, o lado oculto do receptor, organizado por Mauro Wilton de Souza.

7 No prefácio à $5^{\underline{a}}$ edição espanhola (publicada em1998), incorporado à edição brasileira de Dos meios às mediações sob o título de Pistas para entre-ver meios e mediações.

8 Ofício de Cartógrafo foi publicado originalmente no México, em 2002.

9 Chamamos a atenção para o fato de que, nessa passagem, gênero aparece como família de textos.

${ }^{10}$ Ver em Gomes, 2004, p. 133-144, uma análise de como Raymond Williams se apropria da perspectiva cultural de Antonio Gramsci para construir uma teoria cultural marxista que não reduzisse a cultura a um mero reflexo das relações de produção.

11 Tradução nossa. Certamente, nem Martín-Barbero nem nós mesmos concordamos com a decadência da perspectiva sociológica frente à semiótica no estudo da comunicação, decadência postulada por Fabbri no artigo citado.

12 Fazemos a citação a partir de Dos meios às mediações, mas em Martín-Barbero, 2004, p. 236 o autor repete o argumento nessa mesma formulação.

\section{REFERÊNCIAS}

BOURDIEU, Pierre. Meditações pascalianas, Rio de Janeiro: Bertrand Brasil, 2001.

BUTSCH, Richard. Five decades and three hundred sitcoms about class and gender. In: EDGERTON, Gary R.; ROSE, Brian (Ed.). Thinking outside the box. A contemporary television genre reader. Kentucky: The University Press of Kentucky, 2008. p. 111-135. 
CAWELTI, John G. The Six-Gun Mystique. Ohio: Bowling Green University Popular Press, 1971.

EDGERTON, Gary R.; ROSE, Brian (Ed.). Thinking outside the box. A contemporary television genre reader. Kentucky: The University Press of Kentucky, 2008.

FABBRI, Paolo. Le comunicazioni di massa in Italia: sguardo semiótico e malocchio de La sociologia. Versus, n. 5, maio/ago. 1973. Disponível em: <www.semioticamente.it/versus/files/fabbri-vs5.pdf>. Acesso em: 12 maio 2009.

GOMES, Itania Maria Mota. A noção de gênero televisivo como estratégia de interação: o diálogo entre os cultural studies e os estudos da linguagem. In. Revista Fronteira, São Leopoldo, v. 4, n. 2, p. 11-28, 2002.

Efeito e Recepção: a interpretação do processo receptivo em duas tradições de investigação sobre os media. Rio de Janeiro: E-Papers, 2004.

Questões de método na análise do telejornalismo: premissas, conceitos, operadores de análise. Revista E-compos, ed. 8, abril, 2007. Disponível em: <http://www .compos.org.br/seer/index.php/e-compos/article/view/126/126> Acesso em: 12 maio 2009.

JONES, Jeffrey P. Beyond genre: cable's impact on the talk show. In: EDGERTON, Gary R.; ROSE, Brian (Ed.). Thinking outside the box. A contemporary television genre reader. Kentucky: The University Press of Kentucky, 2008. p. 156-175.

MARTÍN-BARBERO, Jesús. De los medios a las mediaciones. Comunicación, cultura y hegemonía. México: Gustavo Gilli, 1987.

De los medios a las practicas. In: Cuadernos de comunicación y prácticas sociales, México, n. 1, p. 9-18, 1990.

. La comunicación en las transformaciones del campo cultural. Alteridades, México, v. 3, n. 5, p. 59-68, 1993.

. América Latina e os anos recentes: o estudo da recepção em comunicação social. In: SOUSA, Mauro Wilton de (Org.). Sujeito, o lado oculto do receptor. São Paulo: Brasiliense, 1995, p. 39-68.

. Experiencia audiovisual y desorden cultural. In: MARTİN-BARBERO, Jesús; ROCHE, Fábio López de la (Eds.). Cultura, medios y sociedad. Colombia: Ces/Universidad Nacional, 1998, p. 27-64.

Aventuras de un cartógrafo mestizo en el campo de la comunicación. In: Revista Latina de Comunicación Social, La Laguna (Tenerife), n. 19, jul. 1999. Disponível em: <http://www.ull.es/publicaciones/latina/a1999fjl/64jmb htm>. 2004

Ofício de Cartógrafo. Travessias latino-americanas da comunicação na cultura. São Paulo: Edições Loyola,

Dos meios às mediações. Comunicação, Cultura e Hegemonia. Rio de Janeiro: Ed. UFRJ, 2006a.

. Pistas para entre-ver meios e mediações. In: Dos meios às mediaçães. Comunicação, Cultura e Hegemonia. Rio de Janeiro: Ed. UFRJ, 2006b. p. 11-21. 
NEWCOMB, Horace. Reflections on TV: The Most Popular Art. In: EDGERTON, Gary R.; ROSE, Brian (Ed). Thinking outside the box. A contemporary television genre reader. Kentucky: The University Press of Kentucky, 2008. p. 17-36.

The Most Popular Art. New York: Anchor Press, 1974.

PECORA, Norma. The changing face of children's television. In: EDGERTON, Gary R.; ROSE, Brian (Ed). Thinking outside the box. A contemporary television genre reader. Kentucky: The University Press of Kentucky, 2008. p. 91-110.

RONSINI, Veneza V. Mayora. A perspectiva das mediações de Jesús Martín-Barbero (ou como sujar as mãos na cozinha da pesquisa empírica de recepção). In: XIX Encontro da Compós. Rio de Janeiro: PUC-RJ, 2010.

WILLIAMS, Raymond. Marxismo e literatura. Rio de Janeiro: Jorge Zahar, 1979. 